ments (125 and $175 \mathrm{mg} \mathrm{N} / \mathrm{liter}$ ) that gave optimal plant growth and quality fell within these ranges (Table 2). Thus, the values obtained by PT for these two treatments could be used to predict nutrient status for optimal growth of poinsettia. For example, if one used the PT method and obtained EC and $\mathrm{NO}_{3}-\mathrm{N}$ values ranging from 2.5 to $3.2 \mathrm{dS} \cdot \mathrm{m}^{-1}$ and 230 to $312 \mathrm{mg} \cdot$ liter $^{-1}$, respectively, optimal growth and quality of poinsettia could be expected, provided environmental factors were not limiting. The above values are predicted values from regression analysis of data in Table 2 rather than the actual values.

This work supports the use of PT as a rapid and easy method for monitoring medium soluble salts and specific nutrients to indicate whether optimal nutrient levels are present for promotion of plant growth. We caution about the use of standard values established for other extraction techniques for making assessments of the nutritional status of a crop with the PT method. Additional work and grower experiences are needed to establish PT medium nutrient levels that promote optimal growth of other greenhouse crops.

\section{Literature Cited}

Mengel, K. and E.A. Kirkby. 1987. Principles of plant nutrition. 4th ed. Intl. Potash Inst., Bern, Switzerland.

Peterson, H.C. and G. Chesters. 1964. A reliable total nitrogen determination on plant tissue accumulating nitrate nitrogen. Agron. J. 56:8990

Poole, R.T. and A.R. Chase. 1987. Response of foliage plants to fertilizer application rates and associated leachate conductivity. HortScience 22:317-318.

SAS Institute. Inc. 1985. SAS user's guide: Statistics. version 5 (cd.). SAS Institute, Inc. Cary, N.C.

Warncke, D.D. 1986. Analyzing greenhouse growth media by the saturation extraction method. HortScience 21:223-225.

Wright, R.D. 1986. The pour-through nutrient extraction procedure. HortScience 21:227-229.

Wright, R.D. 1987. The Virginia Tech liquid fertilizer system for container grown plants. Virginia. Polytechnic Institute and State Univ., College of Agriculture and Life Sciences Inf. Ser. 86-5.

Yeager, T. H., R.D. Wright, and S.S. Donohue. 1983. Comparison of pour-through and saturated pine bark extract, $\mathrm{N}, \mathrm{P}, \mathrm{K}$, and $\mathrm{pH}$ levels. J. Amer. Soc. Hort. Sci. 108:112-114.

\title{
Leaf Tipburn in Cauliflower as Affected by Cultivar, Calcium Sprays, and Nitrogen Nutrition
}

\author{
Carl J. Rosen \\ Department of Soil Science, University of Minnesota, St. Paul, \\ MN 55108
}

Additional index words. Brassica oleracea, botrytis.

\begin{abstract}
Two separate field experiments were conducted to determine the influence of Ca sprays and $\mathbf{N}$ fertilizer rate on leaf tipburn incidence in 'Snow Crown', 'Self Blanche', and 'Imperial 10-6' cauliflower. Incidence of leaf tipburn was highest in 'Snow Crown' each year and varied with year in 'Self Blanche' and 'Imperial 10-6'. Delaying planting of 'Snow Crown' by 3 weeks decreased tipburn incidence by $20 \%$ and decreased the number of tipburned leaves per tipburned plant by $60 \%$. Sprays of $\mathrm{CaCl}_{2}$ or calcium chelate had no effect on cauliflower productivity, nutrition, or tipburn incidence. Increasing N fertilizer rate from $67 \mathrm{~kg}$ N/ha to $201 \mathrm{~kg} \mathrm{~N} / \mathrm{ha}$ linearly increased yield without significantly affecting tipburn incidence. Concentrations of $\mathrm{Ca}$ in tips of nontipburned leaves were two to five times greater than those in tips of tipburned leaves of comparable physiological age. Basal leaf regions had similar Ca concentrations, regardless of tipburn status. Use of resistant cultivars appears to be the best method of reducing tipburn incidence in cauliflower.
\end{abstract}

Leaf tipburn in cauliflower is characterized as a tip necrosis of young expanding leaves surrounding the enlarging curd. $\mathrm{Ne}$ crotic leaves can lower product quality and, in severe cases, may discolor the curd due to secondary pathogen infection and cause a loss in marketable heads (Maynard et al., 1981). Similar disorders have been reported in other vegetable crops, including cabbage (Maynard et al., 1965), brussels sprouts

Received for publication 5 July 1989. Paper no. 17,432 of the Journal Series, Minnesota Agricultural Experiment Station. I thank Glenn Titrud for assisting with field plot maintenance. The cost of publishing this paper was defrayed in part by the payment of page charges. Under postal regulations, this paper therefore must be hereby marked advertisement solely to indicate this fact.
(Maynard and Barker, 1972), and lettuce (Thibodeau and Minotti, 1969) and all have been related to $\mathrm{Ca}$ nutrition. Maynard et al. (1981) reported that $\mathrm{Ca}$ concentrations in cauliflower leaves were generally lower in tipburned regions of leaves than in similar regions in nontipburned leaves. A Ca gradient within tipburned leaves has also been reported, with lower concentrations near the leaf tip and higher concentrations near leaf basal areas (Rosen et al., 1987). Although Ca nutrition has been implicated in these disorders, applications of $\mathrm{Ca}$ to the soil in field studies have shown inconsistent effects on preventing tipburn incidence (Rosen et al., 1987). Effects of foliar applications of $\mathrm{Ca}$ sprays were not successful in preventing tipburn incidence in lettuce (Misaghi et al., 1981), but no data could be found for cauliflower.
Exploiting genotypic differences in susceptibility to tipburn has been an effective means of reducing the problem (Nieuwhof, 1960). Tipburn incidence, however, can be modified by several environmental factors, including relative humidity, temperature, soil moisture, and soil fertility (Collier and Tibbitts, 1982). Increasing the air temperature, lack of soil moisture, or excessive soil moisture tend to enhance tipburn incidence. One common characteristic of tipburn is that occurrence is usually greatest in young, rapidly growing leaf tissue, particularly during curd enlargement. High rates of $\mathrm{N}$ fertilizer have been reported to increase incidence and/or severity of tipburn in cauliflower (Jenkinson and Campbell, 1957) and cabbage (Nieuwhof et al., 1960). The finding with cauliflower prompted Jenkinson and Campbell (1957) to suggest that tipburn-resistant genotypes be selected under conditions of high $\mathrm{N}$ fertility.

The objective of the present experiments was to evaluate the response of three commonly grown cauliflower cultivars to foliarapplied Ca sprays and $\mathrm{N}$ nutrition in relation to productivity, nutrition, and tipburn incidence.

The study was conducted over 2 years (1986-1987) at the Sand Plain Research Farm in Becker, Minn., on a Hubbard loamy sand (Udorthentic Haploboroll). Soil properties before planting were similar each year. Selected chemical properties averaged over years are as follows (0 to $15 \mathrm{~cm}$ ): organic matter (wet digestion), 2.3\%; $\mathrm{pH}$ [1 soil : 1 water (w/v)] 6.4; P (Bray Pi), $37 \mathrm{mg} \cdot \mathrm{kg}^{-1} ; \mathrm{K}, \mathrm{Ca}$, and $\mathrm{Mg}$ (1 N ammonium acetate), 135, 694, and $192 \mathrm{mg} \cdot \mathrm{kg}^{-1}$ respectively, Extractable nitrate-N $(2 \mathrm{~N} \mathrm{KCl})$ in the top $0.3 \mathrm{~m}$ was 6 $\mathrm{mg} \cdot \mathrm{kg}^{-1}$.

In 1986, the effects of foliar-applied Ca sprays on tipburn incidence and cauliflower productivity were evaluated. In 1987, using the same cultivars, the effects of $\mathrm{N}$ nutrition and planting date were. evaluated. In both years, 'Snow Crown' (early season maturing), 'Imperial 10-6' (mid- to late-season 
Table 1. Effect of cultivar and foliar Ca sprays on cauliflower yield, tipburn incidence, and nutrient composition of recently matured wrapper leaves (1986).'

\begin{tabular}{|c|c|c|c|c|c|c|c|c|c|}
\hline \multirow[b]{2}{*}{ Criterion $^{y}$} & \multicolumn{2}{|c|}{ Yield $\left(\mathrm{Mg} \cdot h \mathrm{a}^{-1}\right)$} & \multirow{2}{*}{$\begin{array}{c}\text { Tipburned plants } \\
(\%)\end{array}$} & \multirow{2}{*}{$\begin{array}{c}\text { Tipburned leaves } \\
\text { per tipburned plant }\end{array}$} & \multicolumn{5}{|c|}{ Leaf nutrient composition (\%) } \\
\hline & Total & Marketable & & & $\mathrm{N}$ & $\mathrm{P}$ & $\mathrm{K}$ & $\mathrm{Ca}$ & $\mathrm{Mg}$ \\
\hline \multicolumn{10}{|l|}{ Cultivar means } \\
\hline Snow Crown & $20.8 \mathrm{~b}$ & $19.9 \mathrm{~b}$ & $97.7 \mathrm{a}$ & $8.5 \mathrm{a}$ & $4.10 \mathrm{a}$ & $0.52 \mathrm{~b}$ & $3.27 \mathrm{~b}$ & $1.01 \mathrm{a}$ & $0.30 \mathrm{a}$ \\
\hline Self Blanche & $23.7 \mathrm{a}$ & $22.5 \mathrm{a}$ & $12.8 \mathrm{c}$ & $3.8 \mathrm{~b}$ & $4.18 \mathrm{a}$ & $0.56 \mathrm{a}$ & $3.43 \mathrm{a}$ & $0.74 \mathrm{~b}$ & $0.27 \mathrm{~b}$ \\
\hline \multicolumn{10}{|c|}{ Calcium treatment means } \\
\hline Control & $24.1 \mathrm{a}$ & $22.7 \mathrm{a}$ & $53.1 \mathrm{a}$ & $6.0 \mathrm{a}$ & $3.91 \mathrm{a}$ & $0.52 \mathrm{a}$ & $3.24 \mathrm{a}$ & $0.77 \mathrm{a}$ & $0.26 \mathrm{a}$ \\
\hline
\end{tabular}

${ }^{2}$ Mean separations, within column and main effect, by Duncan's multiple range tes $P=0.05$.

The cultivar $\times \mathrm{Ca}$ interaction was nonsignificant in all cases.

'Analysis of variance carried out using inverse sine transformation. Data are presented in original scale,

Table 2. Effect of cultivar/planting date and $\mathrm{N}$ fertilizer on cauliflower yield, tipburn incidence, and nutrient composition of recently matured wrapper leaves (1987).

\begin{tabular}{|c|c|c|c|c|c|c|c|c|c|}
\hline \multirow[b]{2}{*}{ Criterion } & \multicolumn{2}{|c|}{ Yield $\left(\mathrm{Mg} \cdot \mathrm{ha}^{-1}\right)$} & \multirow{2}{*}{$\begin{array}{c}\text { Tipburned plants } \\
(\%)\end{array}$} & \multirow{2}{*}{$\begin{array}{l}\text { Tipburned leaves } \\
\text { per tipburned plant }\end{array}$} & \multicolumn{5}{|c|}{ Leaf nutrient composition (\%) } \\
\hline & Total & Marketable & & & $\mathrm{N}$ & $\mathrm{P}$ & $\mathrm{K}$ & $\mathrm{Ca}$ & $\mathrm{Mg}$ \\
\hline \multicolumn{10}{|l|}{$\begin{array}{l}\text { Cultivar/planting } \\
\text { date means }\end{array}$} \\
\hline $\begin{array}{l}\text { Snow Crown-early } \\
\text { planting } \\
\text { Snow Crown-late }\end{array}$ & $17.2 \mathrm{a}$ & $10.6 \mathrm{ab}$ & 97.8 a & $9.7 \mathrm{a}$ & $2.88 \mathrm{~b}$ & $0.45 \mathrm{bc}$ & $3.09 \mathrm{~b}$ & $0.63 \mathrm{a}$ & $0.23 \mathrm{~b}$ \\
\hline planting & $17.0 \mathrm{a}$ & $9.0 \mathrm{~b}$ & $77.5 \mathrm{~b}$ & $3.5 \mathrm{~b}$ & $2.90 \mathrm{~b}$ & $0.50 \mathrm{a}$ & $3.22 \mathrm{a}$ & $0.49 \mathrm{c}$ & $0.22 \mathrm{~b}$ \\
\hline Imperial $10-6$ & $18.2 \mathrm{a}$ & $13.1 \mathrm{a}$ & $16.9 \mathrm{c}$ & $2.2 \mathrm{c}$ & $2.26 \mathrm{c}$ & $0.43 \mathrm{c}$ & $2.84 \mathrm{c}$ & $0.55 \mathrm{~b}$ & $0.18 \mathrm{c}$ \\
\hline Self Blanche & $13.9 \mathrm{~b}$ & $8.2 \mathrm{~b}$ & $70.6 \mathrm{~b}$ & $4.6 \mathrm{~b}$ & $3.17 \mathrm{a}$ & $0.47 \mathrm{~b}$ & $3.16 \mathrm{ab}$ & $0.62 \mathrm{a}$ & $0.25 \mathrm{a}$ \\
\hline $\begin{array}{l}\text { Nitrogen treatment } \\
\text { means }\left(\mathrm{kg} \cdot \mathrm{ha}^{-1}\right)\end{array}$ & & & $\cdot$ & & & & & & \\
\hline 67 & 11.4 & 1.1 & 70.2 & 5.3 & 2.14 & 0.43 & 2.99 & 0.58 & 0.21 \\
\hline 134 & 17.3 & 11.5 & 69.4 & 5.0 & 2.78 & 0.47 & 3.12 & 0.55 & 0.22 \\
\hline 201 & 21.2 & 18.2 & 57.4 & 4.7 & 3.48 & 0.49 & 3.12 & 0.58 & 0.24 \\
\hline Linear & $* *$ & ** & NS & NS & ** & $* *$ & NS & NS & $* *$ \\
\hline Quadratic & NS & NS & NS & NS & NS & NS & NS & NS & NS \\
\hline Interaction & & & & & & & & & \\
\hline Cultivar/plant $\times \mathrm{N}$ rate & NS & NS & NS & NS & NS & NS & NS & ** & NS \\
\hline
\end{tabular}

${ }^{x}$ Meams separations, within colums and Main effect, by Duncans multiple range test, $\mathrm{P}=0.05$. Nonsignificant (NS) or significant at $\mathrm{P}=0.01(* *)$

'Arralysis of variance carried out using inverse sine transformation. Data are presented in original scale.

Table 3. Effect of cultivar/planting date and $\mathrm{N}$ interaction on Ca composition of recently matured cauliflower leaves (1987).

\begin{tabular}{|c|c|c|c|c|}
\hline \multirow{3}{*}{$\begin{array}{l}\text { N rate } \\
\left(\mathrm{kg} \cdot \mathrm{ha}^{-1}\right)\end{array}$} & \multicolumn{4}{|c|}{ 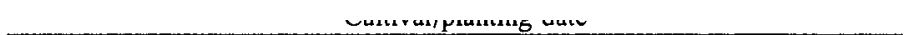 } \\
\hline & Snow Crown (early) & Snow Crown (late) & Imperial 10-6 & Self Blancl \\
\hline & \multicolumn{4}{|c|}{$\% \mathrm{Ca}$} \\
\hline 67 & 0.57 & 0.52 & 0.60 & 0.63 \\
\hline 134 & 0.58 & 0.46 & 0.55 & 0.61 \\
\hline 201 & 0.73 & 0.49 & 0.50 & 0.61 \\
\hline Linear $\mathrm{N}$ rate & $* *$ & * & $* *$ & NS \\
\hline Quadratic $N$ rate & * & *** & NS & NS \\
\hline
\end{tabular}

NS,***Nonsignificant or significant at $P=0.05$ or 0.01 , respectively.

maturing), and 'Self Blanche' (late-season maturing) cauliflower were initially grown as transplants in the greenhouse. Seeds were planted the last week in May in transplant flats containing a 1 peat : 1 sand : 1 soil mixture (by volume). Two weeks after emergence, seedlings were fertilized with $\left(\mathrm{mg} \cdot\right.$ liter $\left.^{-1}\right) 1.00 \mathrm{~N}, 44 \mathrm{P}$, and $81 \mathrm{~K}$ at each irrigation. In 1987, a second seeding of 'Snow Crown' was planted on 19 June. Before planting, $50 \mathrm{~kg} \mathrm{~K} / \mathrm{ha}, 40 \mathrm{~kg} \mathrm{~S} / \mathrm{ha}$, and $25 \mathrm{~kg}$ $\mathrm{Mg} / \mathrm{ha}$ as potassium-magnesium sulfate was broadcast and disked in the field. Overhead irrigation was used to supplement rainfall to provide a total of $35 \mathrm{~mm}$ of water per week.
In 1986, the treatments included three cultivars and three $\mathrm{Ca}$ sprays in a randomized complete block factorial arrangement using four replications. Transplants were planted on 30 June and supplied with 0.3 liter of starter solution $[800 \mathrm{~N}-800 \mathrm{P}-460 \mathrm{~K}$ $\left(\mathrm{mg} \cdot\right.$ liter $\left.\left.^{-1}\right)\right]$ in each transplant hole. Spacing was $0.41 \mathrm{~m}$ within the row and $0.91 \mathrm{~m}$ between rows. Each plot consisted of four 4.9-m rows. Seven days after planting, 27 $\mathrm{kg} \mathrm{N} / \mathrm{ha}, 17 \mathrm{~kg} \mathrm{P} / \mathrm{ha}, 105 \mathrm{~kg} \mathrm{~K} / \mathrm{ha}$, and 1.1 $\mathrm{kg} \mathrm{B} / \mathrm{ha}$ were banded $5 \mathrm{~cm}$ deep and $8 \mathrm{~cm}$ to the side of each plant. Additional $\mathrm{N}$ as ammonium nitrate $(56 \mathrm{~kg} \mathrm{~N} / \mathrm{ha})$ was sidedressed at 21,36 , and 48 days after trans- planting to provide $201 \mathrm{~kg} \mathrm{~N} / \mathrm{ha}$ for the growing season; this total includes $6 \mathrm{~kg} \mathrm{~N} /$ ha from the starter solution. The foliar $\mathrm{Ca}$ spray treatments included: 1) water-sprayed control, 2) $\mathrm{CaCl}_{2} \cdot 2 \mathrm{H}_{2} \mathrm{O}(27 \% \mathrm{Ca})$, and 3) calcium trihydroxyglutarate (Nutri-Cal, $8 \%$ Ca; CSI Chemical Corp., Bondurant, Iowa). Calcium chloride was applied at the rate of $1.8 \mathrm{~kg} \mathrm{Ca} / \mathrm{ha}$ per application mixed with 380 liters of water. Calcium chelate was applied at the rate of $1.0 \mathrm{~kg} \mathrm{Ca} / \mathrm{ha}$ mixed with 95 liters of water. All treatments, including the water-sprayed control, were applied with $\mathrm{X}$ 77 surfactant (Chevron Chemical Co., San Francisco) at the rate of $0.06 \% \mathrm{v} / \mathrm{v}$. The first spray was applied 4 weeks after transplanting. 'Snow Crown' was sprayed twice more, and 'Self Blanche' and 'Imperial 10-6' were sprayed three more times at 7-day intervals. Heads were not tied. The middle $3.3 \mathrm{~m}$ in the center two rows ( 16 heads per plot) were harvested when curd diameter was between 13 and $17 \mathrm{~cm}$. At each harvest date, the number of tipburned leaves per plant and trimmed curd fresh weight were recorded.

In 1987, the same three cultivars were transplanted into the field 1 July, and a second planting of 'Snow Crown' was transplanted 20 days later. In a $4 \times 3$ factorial 
Table 4. Effect of $\mathrm{N}$ fertilizer on $\mathrm{N}$ composition of tip and basaregions of immature tipburned and nontipburned 'Snow Crown' and 'Self Blanche' wrapper leaves sampled at harvest (1987).

\begin{tabular}{|c|c|c|c|c|c|}
\hline \multirow{4}{*}{$\begin{array}{l}\mathrm{N} \text { rate } \\
\left(\mathrm{kg} \cdot \mathrm{ha}^{-1}\right)\end{array}$} & \multirow{4}{*}{$\begin{array}{c}\text { Leaf } \\
\text { region }\end{array}$} & \multicolumn{4}{|c|}{ Cultivar } \\
\hline & & \multicolumn{2}{|c|}{ Snow Crown (late planting) } & \multicolumn{2}{|c|}{ Self Blanche } \\
\hline & & Tipburned & Nontipburned & Tipburned & Nontipburned \\
\hline & & \multicolumn{2}{|c|}{$\% \mathrm{~N}$} & \multicolumn{2}{|c|}{$\% \mathrm{~N}$} \\
\hline $\begin{array}{r}67 \\
134 \\
201 \\
67 \\
134 \\
201\end{array}$ & $\begin{array}{l}\text { Tip } \\
\text { Tip } \\
\text { Tip } \\
\text { Base } \\
\text { Base . } \\
\text { Base }\end{array}$ & $\begin{array}{l}3.48 \\
4.24 \\
4.85 \\
3.02 \\
3.26 \\
4.25\end{array}$ & $\begin{array}{l}2.68 \\
3.48 \\
4.24 \\
2.95 \\
3.71 \\
4.17\end{array}$ & $\begin{array}{l}3.68 \\
3.92 \\
4.40 \\
3.55 \\
3.60 \\
4.39\end{array}$ & $\begin{array}{l}3.80 \\
3.99 \\
3.92 \\
3.87 \\
3.86 \\
3.98\end{array}$ \\
\hline $\begin{array}{r}\text { Sources of } \\
\text { Nitroge } \\
\text { Linea } \\
\text { Quad } \\
\text { Leaf re } \\
\text { Tipbur } \\
\mathrm{N} \times \mathrm{R} \\
\mathrm{N} \times \mathrm{T} \\
\mathrm{R} \times \mathrm{T} \\
\mathrm{N} \times \mathrm{R}\end{array}$ & $\begin{array}{l}\text { ariation }{ }^{2} \\
\text { rate }(N) \\
\text { tic } \\
\text { on }(R) \\
\text { tatus }(T)\end{array}$ & & & $\begin{array}{c}* \\
* \\
\text { NS } \\
\text { NS } \\
\text { NS } \\
\text { NS } \\
* * \\
\text { NS }\end{array}$ & \\
\hline
\end{tabular}

${ }^{2}$ Analyses of variance carried out on data within each cultivar.

$, *, * *$ Nonsignificant or significant at $P=0.0 .5$ or 0.01 , respectively.

Table 5. Effect of $\mathrm{N}$ fertilizer on Ca composition of tip and basal regions of immature tipburned and nontipburned 'Snow Crown' and 'Self Blanche' wrapper leaves at harvest (1987).

\begin{tabular}{|c|c|c|c|c|c|c|}
\hline \multirow{4}{*}{$\begin{array}{l}\text { N rate } \\
\left(\mathrm{kg} \cdot \mathrm{ha}^{-1}\right)\end{array}$} & \multirow{4}{*}{$\begin{array}{l}\text { Leaf } \\
\text { region }\end{array}$} & \multicolumn{5}{|c|}{ Cultivar } \\
\hline & & \multicolumn{3}{|c|}{ Snow Crown (late planting) } & \multicolumn{2}{|c|}{ Self Blanche } \\
\hline & & \multicolumn{2}{|l|}{ Tipburned } & Nontipburned & Tipburned & Nontipburned \\
\hline & & - & $8 \mathrm{Ca}$ & $\cdot$ & \multicolumn{2}{|c|}{$\% \mathrm{Ca}$} \\
\hline 67 & Tip & 0.05 & & 0.35 & 0.33 & 0.75 \\
\hline 134 & Tip & 0.07 & & 0.19 & 0.34 & 0.66 \\
\hline 201 & Tip & 0.08 & & 0.18 & 0.27 & 0.59 \\
\hline 67 & Base & 0.25 & & 0.40 & 0.55 & 0.79 \\
\hline 134 & Base & 0.29 & & 0.32 & 0.57 & 0.63 \\
\hline 201 & Base & 0.35 & & 0.33 & 0.51 & 0.55 \\
\hline \multicolumn{7}{|c|}{ Sources of variation ${ }^{2}$} \\
\hline \multicolumn{2}{|c|}{ Nitrogen rate $(\mathrm{N})$} & \multicolumn{3}{|c|}{ * } & \multicolumn{2}{|l|}{$* *$} \\
\hline \multirow{2}{*}{\multicolumn{2}{|c|}{ Linear }} & \multicolumn{3}{|c|}{ NS } & \multicolumn{2}{|l|}{$* *$} \\
\hline & & \multicolumn{2}{|c|}{ NS } & & \multicolumn{2}{|l|}{ NS } \\
\hline \multicolumn{2}{|c|}{ Leaf region $(R)$} & \multicolumn{2}{|c|}{${ }^{* *}$} & & ** & \\
\hline \multicolumn{2}{|c|}{ Tipburn status (T) } & \multicolumn{2}{|r|}{$* *$} & & $* *$ & \\
\hline \multirow{2}{*}{\multicolumn{2}{|c|}{$\mathrm{N} \times \mathrm{R}$}} & & $*$ & & \multirow{2}{*}{$\begin{array}{l}\text { NS } \\
* *\end{array}$} & \\
\hline & & \multicolumn{2}{|r|}{$* *$} & & & \\
\hline \multicolumn{2}{|c|}{$\mathrm{R} \times \mathrm{T}$} & \multicolumn{2}{|r|}{$* *$} & & ** & \\
\hline \multicolumn{2}{|c|}{$\mathrm{N} \times \mathrm{R} \times \mathrm{T}$} & & NS & & NS & \\
\hline
\end{tabular}

${ }^{2}$ Analyses of variance carried out on data within each cultivar.

ss $* * *$ Nonsignificant or significant at $P=0.05$ or 0.01 , respectively.

treatment arrangement, each cultivar/planting date was provided with three levels of $\mathrm{N}$ fertilizer: 67, 134, and $201 \mathrm{~kg} \mathrm{~N} / \mathrm{ha}$ as ammonium nitrate in two or three split applications. A split-plot design was used with four replications. Nitrogen was the main plot and cultivar/planting date was the subplot. Starter solution, banded fertilizer application, plant population, and plot size were the same as in 1986. In addition to starter solution $\mathrm{N}(6 \mathrm{~kg} \mathrm{~N} / \mathrm{ha})$ and $\mathrm{N}$ supplied 7 days after planting (27 kg N/ha), $34 \mathrm{~kg} \mathrm{~N} / \mathrm{ha}$ was topdressed and irrigated into all plots 21 days after planting. At 35 days after planting, the remainder of the $\mathrm{N}$ fertilizer was topdressed. At this time, the $67-\mathrm{kg} \mathrm{N} / \mathrm{ha}$ treatment did not receive any additional $\mathrm{N}$, the $134-\mathrm{kg} \mathrm{N} / \mathrm{ha}$ treatment received $67 \mathrm{~kg} \mathrm{~N} / \mathrm{ha}$, and the 201- also sampled at harvest. Samples from both tipburned and nontipburned categories were collected from the late-planted 'Snow Crown' and from 'Self Blanche'. Because only a few 'Imperial 10-6' plants exhibited tipburn, only nontipburned plants of this cultivar were sampled. Similarly, all early planted 'Snow Crown' exhibited tipburn and, therefore, only tipburned leaves were sampled. Leaves were cut into tip and basal regions. About $2 \mathrm{~cm}$ of leaf tissue from the tip and base (excluding the midrib) of the leaves were sampled. Leaf tip and basal regions were dried separately and prepared for elemental analyses as described above.

The data were subjected to analysis of variance and means were compared with Duncan's multiple range test. Tipburn incidence percentage data were transformed using the inverse sine conversion before analysis of variance (Steel and Torrie, 1980); however, data are presented on the original scale in the text.

Except for tissue Ca concentrations the 2nd year, interactions between cultivar and nutrition were not significant and, therefore, main effects of cultivar and nutrition will be discussed separately. Symptoms of tipburn first appeared on immature leaves during curd enlargement. In both years, 'Snow Crown' had the highest incidence and greatest severity of leaf tipburn (Tables 1 and 2). 'Self Blanche' had the lowest incidence in 1986 and 'Imperial 10-6' in 1987. Differences in tipburn incidence were not associated with large differences in marketable yield. However, had heads been tied, tipburn may have had more of an impact on marketable yields. Year-to-year variation in cultivar response indicates that environmental conditions can modify the effect due to genotype. Indeed, in the present experiment, delaying transplanting of 'Snow Crown' by 3 weeks decreased tipburn incidence by $20 \%$ and decreased the number of tipburned leaves per tipburned plant by $60 \%$. This decrease in tipburn coincides with an approximate 4C decrease in air temperature during curd enlargement.

Hochmuth (1984) reported that Ca efficiency in cauliflower seedlings, as measured in nutrient solution culture, was greatest in 'Imperial 10-6', intermediate in 'Snow Crown', and lowest in 'Self Blanche'. Results of this field experiment suggest that more than seedling $\mathrm{Ca}$ efficiency is involved in cauliflower leaf tipburn. Significant differences due to cultivar in mature wrapper leaf elemental concentrations were detected both years. 'Imperial 10-6' tended to have lower nutrient concentrations than the other two cultivars.

Foliar-applied $\mathrm{CaCl}_{2}$ or $\mathrm{Ca}$ chelate had no effect on tipburn incidence, yield, or wrapper leaf nutrient composition (Table 1). The difficulty in directing the sprays to expanding young leaves apparently limited the effectiveness of foilar-applied $\mathrm{Ca}$. Although cauliflower leaves were not tied, the growth habit of the plant is such that direct spray contact of young leaves was not uniform with 
the spray procedures used in this study. As a result, levels of $\mathrm{Ca}$ in the inner wrapper leaves were unaffected by the spray treatments. Lack of a consistent response to foliar-applied $\mathrm{Ca}$ in field studies is in agreement with reports for other crops (Misaghi et al., 1981).

Increasing $\mathrm{N}$ fertilizer rate from 67 to 201 $\mathrm{kg} \cdot \mathrm{ha}{ }^{-1}$ linearly increased total and marketable yield (Table 2). This response is similar to that reported for cauliflower by Welch et al. (1987), but is greater than that reported for maximum cauliflower yields by Dufault and Waters (1985). Variable results in response to $\mathrm{N}$ fertilizer may be due' to differences in residual soil nitrate before planting, release of $\mathrm{N}$ from soil organic matter, and/or nitrate leaching during the growing season.

Effects of $\mathrm{N}$ fertilization on the percentage of plants showing tipburn were nonsignificant. In addition, the number of tipburned leaves per tipburned plant was not affected by $\mathrm{N}$ fertilizer application. These results contrast with other reports, where increasing $\mathrm{N}$ fertilizer was associated with an increase in tipburn incidence (Jenkinson and Campbell, 1957; Nieuwhof et al., 1960). The lack of a $\mathrm{N}$ effect on tipburn in the present experiment may be due to the fact that recently developed cultivars generally have been selected under optimum $\mathrm{N}$ fertilizer regimes and those showing a tipburn response under these conditions would have been rogued out, as suggested by Jenkinson and Campbell (1957). Such a practice would tend to minimize the effects of $\mathrm{N}$ on tipburn incidence. In addition, the two lower $\mathrm{N}$ rates used in this study were less than the optimum rate used for cauliflower production. Had excessive rates of $\mathrm{N}$ been used in this study, a different response may have been observed. The results of this experiment clearly indicate that lowering $\mathrm{N}$ fertilizer rates below optimum levels is not an effective control measure for cauliflower tipburn and that significant yield loss may result from such a practice.

Concentrations of $\mathrm{N}, \mathrm{P}$, and $\mathrm{Mg}$ in mature wrapper leaves during head enlargement increased linearly with $\mathrm{N}$ rate (Table 2). Increasing $\mathrm{N}$ rate increased concentrations of leaf $\mathrm{N}$ from $2.14 \%$ to $3.48 \%$. Fertilizer $\mathrm{N}$ effects on tissue $\mathrm{Ca}$ were inconsistent and depended on cultivar (Table 3). Rate of $\mathrm{N}$ had no effect on wrapper leaf Ca concentrations in 'Self Blanche'. In contrast, Ca levels in wrapper leaves increased in early planted 'Snow Crown' and decreased in 'Imperial 10-6' and late-planted 'Snow Crown' with increasing $\mathrm{N}$ rate. In studies with cabbage, increasing $\mathrm{N}$ rate increased $\mathrm{Ca}$ concentrations of the heads at harvest (Peck et al., 1983). The trend for decreasing Ca with increasing $\mathrm{N}$ rate in 'Imperial 10-6' and lateplanted 'Snow Crown' suggests that, in some situations, higher than optimum rates of $\mathrm{N}$ may be associated with increased tipburn incidence. However, in general, low leaf $\mathrm{Ca}$ concentrations in whole, mature wrapper leaves not showing tipburn that were sampled during curd enlargement were not associated with an increase in tipburn incidence. 'Snow Crown' in 1986 and early planted 'Snow Crown' in 1987 had the highest Ca concentrations in mature wrapper leaves, yet showed the greatest tipburn incidence in leaves at harvest.

Concentrations of $\mathrm{N}$ and $\mathrm{Ca}$ in basal and tip regions of immature wrapper leaves from tipburned leaves were compared to concentrations in the same regions from leaves of similar physiological age from nontipburned plants (Tables 4 and 5). Because tipburn incidence was high in early planted, 'Snow Crown', only tipburned leaves were sampled. Concentrations of $\mathrm{N}$ and $\mathrm{Ca}$ in these leaves were similar to tipburned leaves from late-planted 'Snow Crown' (data not presented). Tipburn incidence was low in 'Imperial 10-6'; therefore, only nontipburned leaves were collected. Concentrations of $\mathrm{N}$ and $\mathrm{Ca}$ were similar to 'Self Blanche' nontipburned leaves (data not presented).

Nitrogen concentrations in tip and basal regions increased with $\mathrm{N}$ rate in both 'Self Blanche' and late-planted 'Snow Crown' (Table 4). 'Tip regions of tipburned 'Snow Crown' leaves were higher in $\mathrm{N}$ than corresponding tips from nontipburned leaves. This trend was not observed in 'Snow Crown' basal leaf regions or in either region from 'Self Blanche' leaves.

Leaf $\mathrm{Ca}$ levels were dependent on leaf region, $\mathrm{N}$ rate, and tipburn status (Table 5). Nitrogen rate tended to decrease Ca levels in 'Self Blanche', but had variable effects on Ca levels in 'Snow Crown'. Nontipburned 'Snow Crown' leaves tended to decrease in $\mathrm{Ca}$ levels with $\mathrm{N}$ rate, while tipburned leaves tended to increase. In general, $\mathrm{Ca}$ levels in tips of tipburned leaves were two to five times lower than in tips of nontipburned leaves. Relative Ca differences were greater for 'Snow Crown' than for 'Self Blanche'. There was little difference between $\mathrm{Ca}$ composition of tipburned and nontipburned leaves in basal regions. These results clearly implicate $\mathrm{Ca}$ in the tipburn disorder and support previous reports on leaf tipburn in cauliflower (Krug et al., 1972; Maynard et al., 1981; Rosen et al., 1987). The tipburn problem appears to be due to a localized $\mathrm{Ca}$ deficiency within the leaf and cannot be predicted from $\mathrm{Ca}$ concentrations in whole, mature leaves not showing tipburn damage (Tables 1 and 2).

Results of these experiments suggest that cultivar selection is an effective means of minimizing tipburn incidence in cauliflower. Under the conditions used, foliar applications of $\mathrm{Ca}$ and reducing $\mathrm{N}$ rates below optimum levels were ineffective in controlling the disorder. For susceptible cultivars, such as 'Snow Crown', selecting a planting date to ensure that head maturation occurs during cooler temperatures may help reduce tipburn incidence.

\section{Literature Cited}

Carlson, R.M. 1978. Automatic separation and conductimetric determination of ammonia and dissolved carbon dioxide. Anal. Chem. 50:15281532

Collier, G.F. and T.W. Tibbitts. 1982. Tipburn of lettuce. Hort. Rev. 4:49-65.

Dufault, R.J. and L. Waters, Jr. 1985. Interaction of nitrogen fertility and plant populations on broccoli and cauliflower yields. HortScience 20:127-128.

Hochmuth, G.J. 1984. Variation in calcium efficiency among strains of cauliflower. J. Amer. Soc. Hort. Sci. 109:667-672.

Jenkinson, J.G. and W. Campbell. 1957. Scorch of winter cauliflower. Plant Pathol. 6:92-95.

Krug, H., H.J. Weibe, and A. Jungk. 1972. Calciummangel an Blumenkohl unter Konstanten Klimabedingungen. Z. Pflanzen. Bodenkd. 133:213-226.

Maynard, D.N. and A.V. Barker. 1972. Internal browning of brussels sprouts: A calcium deficiency disorder. J. Amer. Soc. Hort. Sci. 97:789-792.

Maynard, D. N., B. Gersten, and H.F. Vernell. 1965. The distribution of calcium as related to internal tipburn, variety, and calcium nutrition in cabbage. Proc. Amer. Soc. Hort. Sci. 86:392396.

Maynard, D. N., D.C. Warner, and J.C. Howell. 1981. Cauliflower leaf tipburn: A calcium deficiency disorder. HortScience 16:193-195.

Misaghi, I. J., C.A. Matyac, and R.G. Grogan. 1981. Soil and foliar applications of calcium chloride and calcium nitrate to control tipburn of head lettuce. Plant Dis. 65:821-822.

Munter, R. C., T.L. Halverson, and R.D. Anderson. 1984. Quality assurance for plant tissue analysis by ICP-AES. Commun. Soil Sci. Plant Anal. 15:1285-1322.

Nieuwhof, M. 1960. Internal tipburn in white cabbage. I. Variety trials. Euphytica 9:203-208.

Nieuwhof, M., F. Garretsen, and D. Wiering. 1960. Internal tipburn in white cabbage. II. The effect of some environmental factors. Euphytica 9:275280

Peck, N. H., M.H. Dickson, and G.E. MacDonald. 1983. Tipburn susceptibility in semiisogenic inbred lines of cabbage as influenced by nitrogen. J. Amer. Soc. Hort. Sci. 18:726728.

Rosen, C. J., H.J. Buchite, and G.G. Ahlstrand. 1987. Cauliflower response to gypsum on a coarse-textured soil: Relationship between tipbum and leaf nutrient distribution. J. Plant Nutr. 10:1925-1934.

Steel, R.G. and J.H. Torrie. 1980. Principles and procedures of statistics. McGraw-Hill, New York.

Thibodeau, P.O. and P.L. Minotti. 1969. The influence of calcium on the development of lettuce tipburn. J. Amer. Soc. Hort. Sci. 94:372376.

Welch, N. C., K.B. Tyler, and D. Ririe. 1987. Split nitrogen applications best for cauliflower. Calif. Agr. 41:21-22. 